\title{
Atypical bilateral femoral fractures: a rare adverse effect of long-term bisphosphonate use
}

\author{
Oluwatobi 0 Onafowokan
}

Department of Orthopaedic Surgery, Salford Royal Hospital, Salford, UK

\section{Correspondence to} Oluwatobi 0 Onafowokan; tonafowokan7@gmail.com

Accepted 19 August 2021

\section{DESCRIPTION}

A 69-year-old man presented with deformities to his mid-thighs bilaterally and inability to weightbear. He had fallen from standing height after tripping over a loose rug at his home. He suffered no other injuries and examination indicated no neurovascular deficits. Prior to injury, he had been independently mobile and fully weight-bearing without issue. Plain radiographs indicated bilateral femoral shaft fractures (figures 1 and 2). There was no clinical or radiographical evidence of pelvic or proximal femoral fractures. His medical history included osteoporosis, coronary angioplasty and hypertension. His current medication included: risedronate (11 years' use), ramipril, atorvastatin and aspirin. He underwent bilateral fascia iliaca compartment blocks with subsequent intramedullary fracture fixation.

Bisphosphonates (such as risedronate) are a class of drug widely used in the treatment of osteoporosis. They decrease the rate of bone mineral density (BMD) loss by inhibiting osteoclastic bone resorption, the process through which essential minerals such as calcium are reabsorbed from bone. $^{12}$ Adverse effects of bisphosphonate use include musculoskeletal pain, hypocalcaemia, oesophageal irritation, atrial fibrillation and jaw osteonecrosis. $^{2}$

Atypical subtrochanteric femoral insufficiency fractures are an extremely rare adverse effect of long-term bisphosphonate use. They have an estimated incidence of 1 in 1000 per year; however, the evidence suggesting a definitive link is still somewhat controversial. ${ }^{3-5}$ Such fractures may be atraumatic or caused by low-energy impact and are often bilateral. ${ }^{367}$ Affected patients have usually been on $>3-5$ years of bisphosphonate therapy and may report acute-to-chronic histories of thigh or

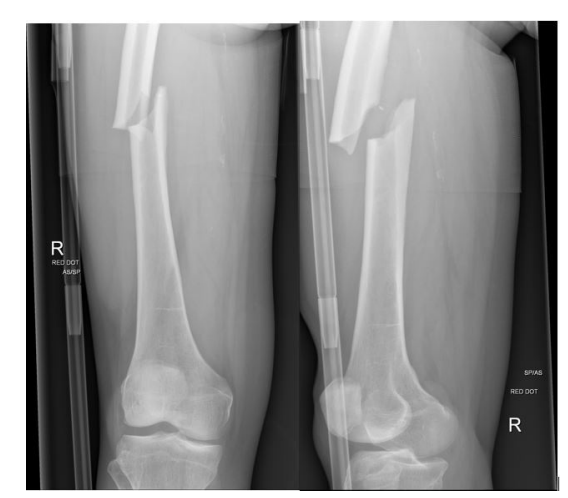

Figure 1 Anteroposterior and lateral plain film radiographs of right femur fracture.

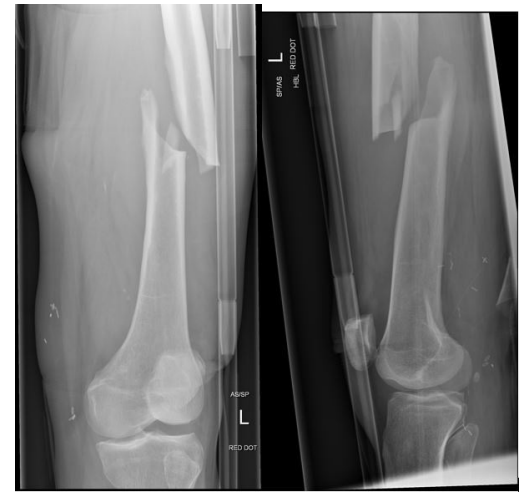

Figure 2 Anteroposterior and lateral plain film radiographs of left femur fracture.

groin pain. ${ }^{34}$ Intramedullary nailing is the recommended mode of treatment. ${ }^{9}$

The mechanism through which bisphosphonates may contribute to atypical fracture patterns, such as in this patient, is yet to be definitively determined. The proposed mechanism is decreased osteoclastic activity and impeded bony remodelling following prolonged bisphosphonate use, which contributes to increased skeletal fragility due to the accumulation of bony microdamages which would otherwise normally be repaired in individuals not on bisphosphonates. ${ }^{4610}$

Although the optimal duration of bisphosphonate therapy remains unclear, recent recommendations suggest a 3-5 year therapy duration $(5$ years for risedronate) for patients at 'low-risk' of fracture, at which time a "drug holiday" and reassessment of BMD should be undertaken. ${ }^{11} 12$

This case adds to the still controversial evidence that bisphosphonates may be linked with atypical femoral fractures. Further research is needed to infer a definitive link. This patient recovered well from his surgery and was discharged 4 weeks later after a period of rehabilitation. On clinical recommendation, he agreed to stop taking risedronate and will undergo BMD reassessment with subsequent discussions concerning further osteoporosis management.

Bisphosphonates are still a very welcome revolutionary drug class for the treatment of osteoporosis. The overall risk of both typical and atypical femoral fractures still remains significantly lower in patients taking bisphosphonates. ${ }^{3}$ However it would be advisable for medical practitioners to engage in regular reviews of long-term medication, patient counselling regarding this rare potential adverse effect and BMD reassessment after 3-5 years of bisphosphonate therapy with consideration of 'drug holidays'. 


\section{Patient's perspective}

I had been on the drug for such a long time. It was part of my regular routine and I had never been told to stop taking it, so I continued. I also couldn't have imagined that the simple fall I had would have caused that much damage to my legs. I'm feeling much better and getting back to how I used to walk. Happy that my case can be used for learning.

\section{Learning points}

- Atypical subtrochanteric fractures are an extremely rare adverse effect following $>3-5$ years of bisphosphonate therapy.

- Patients should be counselled regarding this potential adverse effect, undergo routine reviews of long-term medication and undergo bone mineral density reassessment after $3-5$ years of bisphosphonate therapy.

- In patients shown to have an atypical subtrochanteric femoral fracture on bisphosphonates, consider radiological imaging of the contralateral femur to exclude coexisting impending/ incomplete fractures which may require prophylactic surgical fixation.

Contributors 000 wrote the article, spoke to and consented the patient.

Funding The authors have not declared a specific grant for this research from any funding agency in the public, commercial or not-for-profit sectors.

Competing interests None declared.

Patient consent for publication Obtained.
Provenance and peer review Not commissioned; externally peer reviewed.

\section{ORCID iD}

Oluwatobi O Onafowokan http://orcid.org/0000-0002-7488-3227

\section{REFERENCES}

1 Rodan GA, Fleisch HA. Bisphosphonates: mechanisms of action. J Clin Invest 1996:97:2692-6.

2 Drake MT, Clarke BL, Khosla S. Bisphosphonates: mechanism of action and role in clinical practice. Mayo Clin Proc 2008;83:1032-45.

3 Rizzoli R, Akesson K, Bouxsein M, et al. Subtrochanteric fractures after long-term treatment with bisphosphonates: a European Society on clinical and economic aspects of osteoporosis and osteoarthritis, and international osteoporosis Foundation Working Group report. Osteoporos Int 2011;22:373-90.

4 Yoon RS, Hwang JS, Beebe KS. Long-Term bisphosphonate usage and subtrochanteric insufficiency fractures: a cause for concern? J Bone Joint Surg Br 2011;93:1289-95.

5 Starr J, Tay YKD, Shane E. Current understanding of epidemiology, pathophysiology, and management of atypical femur fractures. Curr Osteoporos Rep 2018;16:519-29.

6 Edwards BJ, Bunta AD, Lane J, et al. Bisphosphonates and nonhealing femoral fractures: analysis of the FDA adverse event reporting system (FAERS) and international safety efforts: a systematic review from the research on adverse drug events and reports (radar) project. J Bone Joint Surg Am 2013;95:297-307.

7 Ogundipe OA. Nontraumatic bilateral atypical femoral fractures associated with longterm alendronate therapy. Int J Basic Clin Pharmacol 2020;9:1737. 9..

8 LeBlanc ES, Rosales AG, Black DM, et al. Evaluating atypical features of femur fractures: how change in radiological criteria influenced incidence and demography of atypical femur fractures in a community setting. J Bone Miner Res 2017;32:2304-14.

9 Donnelly E, Saleh A, Unnanuntana A, et al. Atypical femoral fractures: epidemiology, etiology, and patient management. Curr Opin Support Palliat Care 2012;6:348-54.

10 Isaacs JD, Shidiak L, Harris IA, et al. Femoral insufficiency fractures associated with prolonged bisphosphonate therapy. Clin Orthop Relat Res 2010;468:3384-92.

11 UpToDate. Bisphosphonate therapy for the treatment of osteoporosis [Internet], 2021. Available: https://www.uptodate.com/contents/bisphosphonate-therapy-for-thetreatment-of-osteoporosis\#H1069087

12 National Institute for Health and Care Excellence. Osteoporosis, 2017. Available: https://www.nice.org.uk/guidance/qs149/chapter/Quality-statement-4-Long-termfollow-up

Copyright 2021 BMJ Publishing Group. All rights reserved. For permission to reuse any of this content visit

https://www.bmj.com/company/products-services/rights-and-licensing/permissions/

BMJ Case Report Fellows may re-use this article for personal use and teaching without any further permission.

Become a Fellow of BMJ Case Reports today and you can:

- Submit as many cases as you like

- Enjoy fast sympathetic peer review and rapid publication of accepted articles

- Access all the published articles

- Re-use any of the published material for personal use and teaching without further permission

Customer Service

If you have any further queries about your subscription, please contact our customer services team on +44 (0) 2071111105 or via email at support@bmj.com.

Visit casereports.bmj.com for more articles like this and to become a Fellow 